\title{
THE EFFECT OF OFFLINE LEARNING MODEL ASSISTED IN PRACTICUM DISCOVERY LEARNING ON LEARNING OUTCOMES
}

\author{
Azizah $^{1}$, Siti Fajeriah ${ }^{2}$ \\ Fakultas Keguruan dan Ilmu Pendidikan, Universitas Tadulako, Palu Indonesia \\ azizahrosnadi@gmail.com, sitifajeriah10@gmail.com
}

Received: 02-08-2021 Revised: 18-10-2021 Accepted: 30-10-2021

\begin{abstract}
The purpose of this article was to determine the effect of the offline learning model assisted by the Dilan practicum module on hot material on the learning outcomes of fifth grade students of SD Inpres 1 Ujuna. This type of research is quantitative research with the type of experimental research using the Quasi experimental method with the Nonequivalent Control Group Design design. The subjects in this study were fifth grade students of SD Inpres 1 Ujuna. Data collection was carried out using multiple choice questions, and data analysis used prerequisite tests, namely normality and homogeneity tests and hypothesis testing using independent sample t-test tests which were analyzed using SPSS Statistics version 16. Based on the results of this study, a significant value of $0.001<0,05$ then accept the hypothesis $\mathrm{Ha}$ and reject Ho, meaning that the dilan practicum module has an effect when used in improving student learning outcomes. So it can be concluded that there is an effect when using the offline learning model assisted by Dilan's practical module on hot material on the learning outcomes of fifth grade students of SD Inpres 1 Ujuna.
\end{abstract}

Keywords: Online Learning, Dilan's Practicum Module, Kalor Materials, Learning Outcomes

\begin{abstract}
Abstrak
Tujuan artikel ini adalah untuk mengetabui pengarub model pembelajaran luring berbantuan modul praktikum dilan pada materi panas terbadap hasil belajar siswa kelas V SD Inpres 1 Ujuna. Artikel ini menggunakan jenis penelitian ini adalah penelitian kuantitatif dengan jenis penelitian eksperimen menggunakan metode Quasi expserimental dengan desain Nonequivalent Countrol Group Design. Subyek, pada penelitian ini yaitu siswa kelas V SD Inpres 1 Ujuna. Pengambilan data yang dilakukan menggunakan soal pilihan ganda, dan Analisis data menggunakan uji prasyarat yaitu uji normalitas dan uji homogenitas serta pengujian hipotesis menggunakan uji independen sampel t-test yang dianalisis menggunakan SPSS Statistics versi 16. Berdasarkan hasil penelitian ini menunjukan nilai signifikan 0,001 < 0,05 maka menerima bipotesis $\mathrm{Ha}$ dan menolak $\mathrm{Ho}$, artinya modul praktikum dilan berpengaruh saat digunakan dalam meningkatkan hasil belajar siswa. Jadi dapat disimpulkan bahwa ada Pengaruh saat menggunakan model pembelajaran luring berbantuan modul pratikum Dilan pada materi panas terhadap hasil belajar siswa kelas V SD Inpres 1 Ujuna.
\end{abstract}

Kata Kunci: Pembelajaran Luring, Modul Praktikum Dilan, Materi Panas, Hasil Belajar 


\section{INTRODUCTION}

The coronavirus disease epidemic that was discovered in 2019 (covid-19) has now spread to various regions in Indonesia, this is evidenced by the increasing number of patients exposed to the covid-19 virus. The complexity of handling the Covid-19 virus outbreak has forced the Minister of Education in Indonesia to implement a super-strict policy to break the chain of the spread of COVID-19. One of them is by applying learning at home or another term, namely offline learning. According to Nadiem Anwar Makarim, the home-study program is a form of the Ministry of Education and Culture's efforts to assist the implementation of education for all circles of society during the Covid-19 emergency ${ }^{1}$.

According to Jenri Ambarita, Jarwati \& Dina Kurnia Restanti offline Learning is an abbreviation from outside the network which is a trend being used to replace offline words. Offline is the antonym of online or online. Offline learning actually provides many benefits, although it is not as effective as internet-based online learning. Face-to-face classroom learning in this pandemic condition is not possible but can integrate technology in both online and offline learning ${ }^{2}$.

Offline learning brings benefits to both students and teachers. Offline learning can still be carried out without having to use electronic devices such as laptops, androids, and internet access. One of the benefits of offline learning is helping economically weak students to keep learning. Students from various regions, both in urban and rural areas, can still participate in learning. ${ }^{3}$ The offline learning process requires more facilities such as books, modules, teaching media, and so on. This facility supports students to study independently at home and at school. With the facilities owned by students, it helps the teacher's role in the learning process.

After making initial observations carried out at SD Inpres 1 Ujuna, that the learning they use during the current covid-19 pandemic is online and offline, while offline learning is carried out in schools with 5-6 students at a certain time. Based on the results of observations made with classroom teachers related to the science learning process (Ilum Pengtahuan Alam) several obstacles were found. The obstacles faced by teachers at the school, such as students being less active in the learning process. Learning is teacher center learning, where all learning activities are sourced from the teacher. Student activities are more focused on working on questions so that student learning outcomes decrease. Activities that activate students such as experimental or practical activities have never been carried out.

According to Yuliana S. Patattan \& Huber Yaspin Tandi for a student getting good results is a matter of pride. Students who get good learning outcomes will always try to maintain and improve the learning outcomes they have obtained. However, to get good

\footnotetext{
${ }^{1}$ Azmil Abidah dkk., "The Impact of Covid-19 to Indonesian Education and Its Relation to the Philosophy of 'Merdeka Belajar," Studies in Philosophy of Science and Education 1, no. 1 (1 April 2020): 38-49, https://doi.org/10.46627/sipose.v1i1.9; Beby Masitho Batubara, "The Problems of the World of Education in the Middle of the Covid-19 Pandemic," Budapest International Research and Critics Institute (BIRCI-Journal): Humanities and Social Sciences 4, no. 1 (2021): 450-57.

2 Jarwati dan Dina Kurnia Restianti, PEMBELAJARAN LURING (Jawa Barat: CV Adanu Abimata, 2020).

3 Rusi Rusmiati Aliyyah dkk., "The perceptions of primary school teachers of online learning during the COVID-19 pandemic period: A case study in Indonesia," Journal of Ethnic and Cultural Studies 7, no. 2 (2020): 90109; Harun Serpil, "Book Review Student-Teacher Interaction in Online Learning Environments," The Turkish Online Journal of Distance Education 18, no. 2 (1 April 2017): 202-7, https://doaj.org.
} 
learning outcomes is not easy, because student learning success is influenced by several factors and requires great effort to achieve it. For learning that has psychomotor competence, such as carrying out experiments or trials, it is done by providing an explanation of the material. This happens a lot in science subjects, arts and culture, and Physical Education. The teacher does not carry out practical activities for reasons of limited time and teaching aids ${ }^{4}$.

Science learning is learning that emphasizes providing direct experience using either experiments or observations or others, so that the data obtained are truly valid and can be accounted for. Science subjects are very useful for everyday life and can be taught to students to think critically and logically. This is in line with the opinion of Sujana that science or science is a science that studies the universe and its contents, as well as the events that occur in it which are developed by experts based on scientific processes ${ }^{6}$.

The scientific process includes activities of scientific process skills and scientific attitudes. Science process skills are observing, measuring, communicating, classifying, predicting, and interference/hypothesis. To achieve these process skills, students must carry out experimental or practical activities.

To overcome the problems that occur in SD Inpres 1 Ujuna, one of the solutions offered is to use a learning module. The learning module in question is the Discovery Learning (Dilan) practicum module. The science practicum model with the Discovery Learning (Dilan) approach is a learning media that can be studied independently containing learning objectives, material summaries and practical activities to prove natural phenomena. Practical activities are accompanied by several questions that require students to perform science process skills.

According to Azizah \& Puji Winarti, the objectives of developing the module with a Discovery Learning approach include: 1) So that students can learn independently without or with the guidance of educators. This is in accordance with the characteristics of the Discovery Learning approach; 2) So that the role of educators is not too dominant and authoritarian in learning activities so that students can find their own knowledge; 3) Train students' honesty. With the aim of obtaining new knowledge or proving the phenomenon that occurs, the work steps in practicum activities are made systematically so that students carry out practical activities in accordance with the instructions in the module; 4) Accommodate various levels and learning speed of students. Students who have been able to make their own conclusions can proceed to the next practicum activity; 5) So that students are able to measure their own level of mastery of the material that has been studied. At the end of the module, it is equipped with an evaluation related to the material that has been studied through practical activities ${ }^{7}$.Based on this background, the writer is interested in conducting a research entitled

\footnotetext{
4 Anaas Tri Ridlo Dina Yuliana, "Total Quality Educational Mindset Formation at Muhammadiyah Elementary School Kleco Yogyakarta," Tadris: Jurnal Keguruan Dan Ilmu Tarbiyah 3, no. 1 (29 Juni 2018): 67-76, https://doi.org/10.24042/tadris.v3i1.2391; Yuliana S. Patattan dan Huber Yaspin Tandi, "Hubungan Motifasi Belajar Dengan Hasil belajar Siswa Kleas V SD2 Talise," 2019.

5 Tia Andesti dan Jamaris Jamna, "The Influence of the Team Games Tournament (TGT) Learning Model on the Participation Level of Santri in Fiqh Subjects In Islamic Boarding Schools," SPEKTRUM: Jurnal Pendidikan Luar Sekolah (PLS) 9, no. 1 (28 Februari 2021): 114-22, https://doi.org/10.24036/spektrumpls.v9i1.111366; Oni Arlitasari, Puja Pujayanto, dan Rini Budiharti, "Pengembangan Bahan Ajar Ipa Terpadu Bebasis Salingtemas dengan Tema Biomassa Sumber Energi Alternatif Terbarukan,” Jurnal Pendidikan Fisika 1, no. 1 (2013).

${ }^{6}$ A Sujana, Dasar Dasar IP A : Konsep dan Aplikasinya (Bandung: UPI Press, 2014).

${ }^{7}$ Azizah dan Puji Winarti, "Pengembangan Modul Discon Sains Di Sekolah dasar" 8(3) (2018).
} 
"The Effect of Offline Learning Model Assisted by Dilan Pratikum Module on Hot Materials on Student Learning Outcomes of Class V SD Inpres 1 Ujuna".

\section{METHOD}

The type of experimental research used in this research is Quasi Experimental Research. Quasi-experimental is a method that has control, but cannot fully function to control external variables that affect the experiment. ${ }^{8}$ Quasi-experimental research design used in this study is the Nonequivalent Control Group Design. The design of this study consisted of two control and experimental groups which were then given a pre-test to determine the initial state before the treatment was carried out, then a post-test or final test was given after the treatment, namely whether there was a difference between the experimental group and the control group. The experimental class was given treatment using the Dilan practicum module, and the control class used the learning model treatment that was previously applied to class $\mathrm{V}$ SD Inperes 1 Ujuna.

The subjects of this study were the fifth grade students of SD Inpres 1 Ujuna with a total of 21 students, 14 of whom were male, and 7 were female. These students were used as an experimental class group of 12 people and a control class group of 10 people. The research instrument used was multiple choice questions. Multiple-choice questions in this study aimed to see whether there was an effect before and after being given treatment. Before using the multiple-choice instrument, it was first tested to validate the questions at SDN 4 Palu.

After being tested in class V at SDN 4 Palu, the multiple choice questions were tested for validity and reliability which were analyzed using SPSS Statistics version 16. The data analysis techniques used in this study were descriptive data analysis techniques and inferential data analysis techniques. the description is used to describe the average (mean), minimum, maximum, and standard deviation and inferential data analysis is used to test the hypothesis by using an independent sample t-test to determine whether there is a difference between the results of the data before treatment and after treatment, and the calculation is assisted by SPSS statistics version 16 .

\section{RESULTS AND DISCUSSION}

\section{Findings}

After getting the research data, the next step is to analyze the data. There are two data analysis used in this research, namely descriptive data analysis and inferential data analysis. The results of the pre-test descriptive analysis of the experimental class and the control class can be seen in the following table.

Table 1. Results of Pretest Data Analysis

\begin{tabular}{lcc}
\hline \multirow{2}{*}{ Statistik } & \multicolumn{2}{c}{ Data Pretest } \\
\cline { 2 - 3 } & Experiment Class & Control Class \\
\hline Mean & 46,00 & 47,80 \\
Minimum Scor & 32 & 30 \\
Maximum Scor & 50 & 60 \\
\hline
\end{tabular}

\footnotetext{
${ }^{8}$ Sugiyono, Metode penelitian Kuantitatif Kualitatif dan R\&D, Ed. 14 (Bandung: Alfabeta, 2014).
} 
Based on the table above, the results of the pre-test in the control class averaged a score of 47.8. With a maximum value of 60 and a minimum value of 60 . The average value of learning outcomes in the experimental class after being given a pre-test is 46 . With a maximum value of 50 and a minimum value of 32 . Furthermore, the results of the post-test analysis of the experimental class and control class can be seen in the following table:

Table 2. Post-test Data Analysis Results

\begin{tabular}{lcc}
\hline \multirow{2}{*}{ Statistik } & \multicolumn{2}{c}{ Data Post-test } \\
\cline { 2 - 3 } & Experiment Class & Control Class \\
\hline Mean & 72,25 & 63,80 \\
Minimum Scor & 78 & 50 \\
Maximum Scor & 100 & 90 \\
\hline
\end{tabular}

Based on the analysis data above, it is known that the post-test score of the experimental class has an average (mean) student in the experimental class of 72.25 , a minimum score of 78 , and a maximum score of 100 . The results of the control class post-test have an average of ( the mean) of students is 63.80 , the minimum score is 50 , and the maximum score is 90 .

The results of the description analysis show that there is a difference in the average value of student learning outcomes between the experimental class and the control class. The average value of student learning outcomes in the experimental class is higher than the average value of students in the control class. After descriptive analysis, then perform inferential analysis to see or determine the effect of offline learning model assisted by the dilan module on student learning outcomes on hot material. Inferential analysis includes hypothesis testing and prerequisite tests. The prerequisite tests measured in this study are the normality test and the homogeneity test.

The normality test used in this study was to determine whether the data population in the experimental class and control class were normally distributed or not. The test criteria used to measure the normality of the residuals in this study Ho is accepted if the sign value. obtained $>$ from the level of which is set at 5\% (0.05). The test for normality distribution of residual scores Pretest for the experimental and control classes was carried out using the Kolmogorov-Smirnov test using the SPSS For Windows 16 program. The results of the normality test for the data in the control and experimental classes can be seen in the following table.

Tabel 3. The results of the normality test of the experimental class and control class . data

\begin{tabular}{llc}
\hline \multicolumn{1}{c}{ Data } & & $\begin{array}{c}\text { Unstandardized } \\
\text { Predicted Value }\end{array}$ \\
\hline Experiment Class & Asymp.Sig (2-tailed) & 0,995 \\
Controll Class & Asymp.Sig (2-tailed) & 0,999 \\
\hline
\end{tabular}




\begin{tabular}{llllllll}
\hline $\begin{array}{l}\text { Pair1 } \\
\begin{array}{l}\text { Pretest- } 2.625 \mathrm{E} 1 \\
\text { posttest }\end{array}\end{array}$ & 20.008674 & 5.79854 & -39.0125 & -13.48749 & -4.527 & 11 & .001 \\
\hline
\end{tabular}

Based on Table 5 above, the significance value of Paired Sample T Test is $0.001<0.05$. Because the significant value of t-test $<(0.001<0.05)$ then $\mathrm{Ha}$ is accepted and Ho is rejected. So it was concluded that the use of the offline learning model assisted by the Dilan practicum module on hot materials had an effect on the learning outcomes of 5th grade science at SD Inpres 1 Ujuna.

\section{Discuusion}

The results of testing the hypothesis which stated that Dilan's practicum module on hot materials had an effect on the learning outcomes of 5th grade science at SD Inpres 1 Ujuna. The effect of the learning model assisted by the Dilan practicum module on hot material on the learning outcomes of fifth grade students of SD Inpres 1 Ujuna is indicated by the Sig t-test value in the t-test analysis result table. The column shows that the t-test sign value is smaller than $(0.001<0.05)$. Then the influence of the learning model assisted by the Dilan practicum module on hot material on the learning outcomes of fifth grade students of SD Inpres 1 Ujuna.

The effect of using the Dilan practicum module on hot material on the science learning outcomes of fifth graders at SD Inpres 1 Ujuna was also shown from the Posttest activity carried out at the end of the lesson. The average posttest score for the experimental class was 72.25 while the posttest average for the control group was 63.80 .

The results of the posttest show that the average value obtained by the experimental class in learning science using the dilan practicum module is higher than the average value obtained by the control class in learning science using book media. This means that the use of the dilan practicum module on hot materials affects the learning outcomes of fifth grade science at SD Inpres 1 Ujuna. The results of this study are supported by the theories found previously.

When using the dilan practicum module in the experimental class, it can help students learn and conduct experiments independently, providing more meaningful learning to students because by using the dilan practicum module students will find their own knowledge from the experiments that have been carried out. By using the practicum module, students can find concepts from the material being studied, students will become active and independent in conducting experiments, students will feel happy because they have succeeded in finding new concepts and solving their own problems, students become interested in learning science because science is useful in everyday life. -day and students have a positive outlook on science and scientists.

In accordance with the results of research by Azizah \& Puji Winarti (2018) "Development of the Dilan Practicum Module (Discovery Learning) for Science Learning in Class V Elementary School." Which states that using the dilan practicum module is effectively used in science learning practicum activities in elementary schools. This is evidenced by the results of the questionnaire from the small group trial obtaining a score of 63.80 with very 
practical criteria. Dilan's Practicum Module (Discovery Learning) for science learning in Class V SD has met the effective criteria. This is evidenced by the results of the N-Gain value. Based on the N-Gain analysis, it was found that the N-Gain value in the high category was 0.72. This indicates that the Dilan Practicum Module (Discovery Learning) for science learning in Grade V SD is effectively used in science learning practicum activities in elementary schools.

\section{CONCLUSION}

Based on the data analysis, it can be concluded that the t-test analysis obtained a significance value of 0.001 . Because the significance value of t-test $<(0.001<0.05)$ then $\mathrm{Ha}$ is accepted and Ho is accepted, so it can be concluded that the use of the Dilan practicum module on hot material affects the learning outcomes of 5th grade students in SD Inpres 1 Ujuna.

\section{REFERENCES}

Abidah, Azmil, Hasan Nuurul Hidaayatullaah, Roy Martin Simamora, Daliana Fehabutar, dan Lely Mutakinati. "The Impact of Covid-19 to Indonesian Education and Its Relation to the Philosophy of "Merdeka Belajar."' Studies in Philosophy of Science and Education 1, no. 1 (1 April 2020): 38-49. https://doi.org/10.46627/sipose.v1i1.9.

Aliyyah, Rusi Rusmiati, Reza Rachmadtullah, Achmad Samsudin, Ernawulan Syaodih, Muhammad Nurtanto, dan Anna Riana Suryanti Tambunan. "The perceptions of primary school teachers of online learning during the COVID-19 pandemic period: A case study in Indonesia." Journal of Ethnic and Cultural Studies 7, no. 2 (2020): 90-109.

Andesti, Tia, dan Jamaris Jamna. "The Influence of the Team Games Tournament (TGT) Learning Model on the Participation Level of Santri in Fiqh Subjects In Islamic Boarding Schools." SPEKTRUM: Jurnal Pendidikan Luar Sekolah (PLS) 9, no. 1 (28 Februari 2021): 114-22. https:// doi.org/10.24036/spektrumpls.v9i1.111366.

Arlitasari, Oni, Puja Pujayanto, dan Rini Budiharti. "Pengembangan Bahan Ajar Ipa Terpadu Bebasis Salingtemas dengan Tema Biomassa Sumber Energi Alternatif Terbarukan.” Jurnal Pendidikan Fisika 1, no. 1 (2013).

Azizah, dan Puji Winarti. "Pengembangan Modul Discon Sains Di Sekolah dasar" 8(3) (2018).

Batubara, Beby Masitho. "The Problems of the World of Education in the Middle of the Covid-19 Pandemic." Budapest International Research and Critics Institute (BIRCI-Journal): Humanities and Social Sciences 4, no. 1 (2021): 450-57.

Jarwati, dan Dina Kurnia Restianti. PEMBELAJARAN LURING. Jawa Barat: CV Adanu Abimata, 2020.

Serpil, Harun. "Book Review Student-Teacher Interaction in Online Learning Environments." The Turkish Online Journal of Distance Education 18, no. 2 (1 April 2017): 202-7. https://doaj.org.

Sugiyono. Metode penelitian Kuantitatif Kualitatif dan R\&D. Ed. 14. Bandung: Alfabeta, 2014.

Sujana, A. Dasar Dasar IPA : Konsep dan Aplikasinya. Bandung: UPI Press, 2014. 
Azizah \& Siti Fajeriah

Yuliana, Anaas Tri Ridlo Dina. "Total Quality Educational Mindset Formation at Muhammadiyah Elementary School Kleco Yogyakarta." Tadris: Jurnal Keguruan Dan Ilmu Tarbiyah 3, no. 1 (29 Juni 2018): 67-76. https://doi.org/10.24042/tadris.v3i1.2391.

Yuliana S. Patattan, dan Huber Yaspin Tandi. "Hubungan Motifasi Belajar Dengan Hasil belajar Siswa Kleas V SD2 Talise,” 2019. 